\title{
Research on Investment Structure of Voltage Level Supporting High Quality Development
}

\author{
Shengwei Lu' ${ }^{1}$, Ming Zhou ${ }^{1, *}$, Qiang Wu ${ }^{1}$, Sha Jin $^{1}$, Jiong Yan $^{2}$, Zixia Sang ${ }^{2}$ \\ ${ }^{1}$ State Grid Hubei Electric Power Co.,Ltd., Development Planning Department, Wuhan Hubei, China \\ ${ }^{2}$ State Grid Hubei Economic Research Institute, Communication and intelligent Planning Office, Wuhan Hubei, China
}

\begin{abstract}
In order to deal with the severe external supervision and challenges, and improve the scientific rationality of internal investment structure decision-making, this study explored the idea of voltage level investment structure decision-making considering the power grid development and operation benefits. Firstly, based on the study of the relationship between historical investment scale and power grid indicators, the investment demand of power grid is determined; secondly, the influence path of investment on business efficiency is sorted out, and the differences of investment, capital transfer and depreciation of different voltage levels are studied and determined, and the operation benefit level of the company under different investment schemes is calculated. Finally, the index system of investment structure optimization is constructed to quantify the power grid and benefit status of the company under different investment structures, so as to optimize the company's investment scheme and promote the high-quality development of the company and power grid.
\end{abstract}

\section{Preface}

Under the new energy security strategy of "four revolutions and one cooperation", the reform of power transmission and distribution price, the reform of electricity selling side market and the energy transformation have been promoted in depth. In 2020, the Reform Commission and the State Energy Administration issued the notice on strengthening and standardizing the investment management of power grid planning, which put forward higher requirements on the compliance of investment, rationality of scale, investment direction, coordination with planning and external economic development of power grid companies; at the same time, the new strategic goal of "an international leading energy Internet enterprise with Chinese characteristics" of State Grid Corporation has a great impact on the company New requirements have been put forward for informatization, energy Internet planning and energy storage investment. However, affected by the epidemic situation and severe economic situation at home and abroad, the realization of the company's business objectives is facing great pressure. How to consider the impact on the overall performance of the company at the same time in the investment decisionmaking is imminent; in addition, the company's investment scale and investment structure decisionmaking mainly rely on experience decision-making, lack of scientific and objective quantitative basis, it is difficult to effectively link up external supervision, internal performance objectives and Business needs, it is urgent to build investment scale and structure calculation model to support scientific, efficient, intelligent and accurate investment decision-making.
Starting from the current situation and management objectives of power grid, this paper studies the relationship between historical investment and current situation of power grid, and determines the investment demand of different voltage levels. Secondly, the calculation results of investment demand are brought into the investment impact calculation model to calculate whether the company's benefit level under the investment demand scheme meets the overall performance objectives of the company; thirdly, different investments are constructed based on the principle of meeting the company's performance objectives Finally, the optimal investment scheme is selected through comprehensive comparison, so as to realize the objective and scientific investment decision under the unification of the company's overall performance evaluation objectives and power grid construction objectives, so as to support the high-quality development of the company and the power grid.

\section{Research ideas}

Firstly, this paper studies the relationship between the historical investment and the current situation of the power grid from the current situation and management objectives of the power grid, and determines the investment demand of different voltage levels. Secondly, the measurement results of investment demand are brought into the investment impact calculation model to measure whether the company's benefit level under the investment demand scheme meets the overall performance objectives of the company; thirdly, it constructs different

*Corresponding author: Zhoum50@hb.sgcc.com.cn 
types of investment demand based on the principle of meeting the company's performance objectives Finally, the power grid status and benefit level of the company under different investment structure schemes are calculated, and the optimal investment scheme is selected by comprehensive comparison.

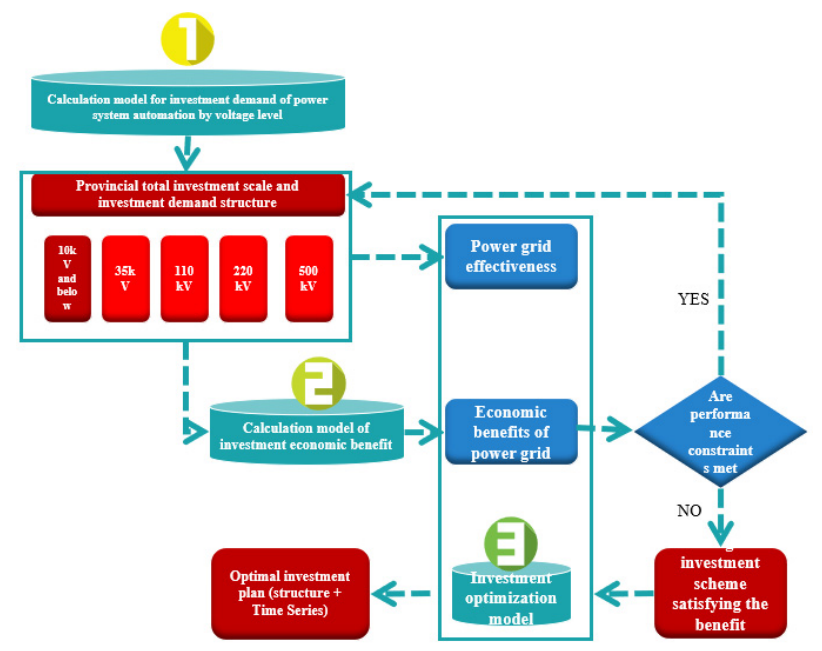

Fig1. Research framework.

\subsection{Investment demand measurement}

The calculation of investment demand based on the current situation of power grid is to determine the effect of unit investment of each type of project by studying the relationship between historical classified investment projects and improvement of power grid status, and calculate the investment demand level of sub voltage level with the evaluation index of power grid status reaching the operation and management objectives as the goal. The first is to determine the investment demand evaluation index system based on the power grid development diagnosis indicators and the key indicators of the company's investment analysis. The second is to study and calculate the improvement level of indicators brought by the investment of classified projects over the years. Third, according to the current situation of power grid and management objectives, calculate the index deviation, and determine the investment demand according to the improvement level of investment indicators over the years.

\subsubsection{Establishing the evaluation index of investment demand}

Considering the difference of investment demand and key points between main network and distribution network, and considering the key points of investment effect of classified projects, based on power grid development diagnosis index, this paper distinguishes main network and distribution network, and establishes grid investment demand rating index system from three dimensions of power development, load development and power grid security. This paper clarifies the principle of index calculation, the basic data of indicators, and the source of data system, which lays the foundation for the construction of investment demand evaluation model.
Based on the current situation of power grid, the demand of power grid construction is considered from three dimensions of power supply development, load development and power grid security. The investment motivation of the project is analyzed from four aspects of power supply access, meeting new load, solving heavy overload and strengthening grid structure. The key indicators that can reflect the demand of power grid construction are selected according to $500 \mathrm{kV}, 220 \mathrm{kV}$, $110 \mathrm{kV}$ and $35 \mathrm{kV}$, and the investment demand index evaluation is formulated Price system.

Table 1. Main network evaluation index system.

\begin{tabular}{|c|c|c|}
\hline $\begin{array}{l}\text { Demand } \\
\text { Dimension }\end{array}$ & $\begin{array}{l}\text { Management } \\
\text { Indicators }\end{array}$ & $\begin{array}{c}\text { Investment performance } \\
\text { indicators }\end{array}$ \\
\hline $\begin{array}{l}\text { Power } \\
\text { development }\end{array}$ & $\begin{array}{l}\text { Installed capacity of } \\
\text { power supply }\end{array}$ & $\begin{array}{l}\text { Installed capacity of power } \\
\text { supply }\end{array}$ \\
\hline \multirow{3}{*}{$\begin{array}{c}\text { Load } \\
\text { development }\end{array}$} & $\begin{array}{l}\text { Variable } \\
\text { capacitance load } \\
\text { ratio }\end{array}$ & $\begin{array}{l}\text { New construction capacity } \\
\text { of main transformer }\end{array}$ \\
\hline & \multirow{2}{*}{$\begin{array}{l}\text { Unit line support } \\
\text { power load }\end{array}$} & Length of new line \\
\hline & & $\begin{array}{l}\text { Length of supporting } \\
\text { transmission line }\end{array}$ \\
\hline \multirow{4}{*}{$\begin{array}{l}\text { Power grid } \\
\text { security }\end{array}$} & \begin{tabular}{|l|}
$\begin{array}{l}\text { Proportion of main } \\
\text { transformer with } \\
\text { heavy overload }\end{array}$ \\
\end{tabular} & $\begin{array}{l}\text { Number of main } \\
\text { transformers to eliminate } \\
\text { heavy overload }\end{array}$ \\
\hline & $\begin{array}{l}\text { Proportion of heavy } \\
\text { overload lines }\end{array}$ & $\begin{array}{l}\text { Number of lines to } \\
\text { eliminate heavy overload }\end{array}$ \\
\hline & $\begin{array}{l}\text { Main transformer } \\
\mathrm{N}-1 \text { passing rate }\end{array}$ & $\begin{array}{l}\text { Eliminating the number of } \\
\text { main transformers not } \\
\text { satisfying N-1 }\end{array}$ \\
\hline & $\begin{array}{l}\text { Line N-1 passing } \\
\text { rate }\end{array}$ & $\begin{array}{l}\text { Eliminate the number of } \\
\text { lines not meeting N-1 } \\
\text { requirements }\end{array}$ \\
\hline
\end{tabular}

Based on the current situation of power grid, this paper considers the demand of power grid construction from three dimensions of power supply development, load development and power grid security, analyzes the project investment motivation from nine aspects: power supply access, meeting new load, eliminating security risks, improving power supply reliability, solving high loss distribution transformer, solving heavy overload, distribution automation, solving low voltage in substation area and improving grid structure To upgrade the key index of distribution network construction demand and establish the index evaluation system.

\subsubsection{Calculation of investment standards for classified projects}

According to the change of investment performance index of different voltage levels in historical years and the change of corresponding project investment scale, the investment amount of unit investment performance index change is calculated, and the average level of historical year is used as the investment standard of classified project for index improvement. That is: the required investment amount of unit investment effectiveness index $=$ the investment amount of investment project 
corresponding to the investment performance index / the change value of the investment effectiveness index.

\subsubsection{Determination of management target value}

First of all, collect the relevant information about the asset structure of different voltage levels of advanced power grid companies in Jiangsu, Zhejiang, Guangdong and other advanced power grid companies, and eliminate local characteristic assets, such as UHV, West to East power transmission projects, as the long-term optimization goal of asset structure. Secondly, combined with the company's planning objectives to determine the company's short-term asset structure objectives; finally, combined with the expected value of diagnostic analysis report, determine the target value of the next year's management indicators.

\subsubsection{Determine the investment needs of classified projects}

Firstly, determine the target value of management indicators related to power grid construction of the company; secondly, calculate the target deviation according to the relationship between the target value and the status quo of the indicators; thirdly, determine the performance index deviation under the current management objective deviation according to the relationship between the management indicators and the investment performance indicators; fourthly, calculate the investment amount of future classified projects according to the deviation of the effectiveness indicators and the investment standards of classified projects .

\subsection{Business benefit prediction}

Combing the relationship between investment and performance indicators, the paper constructs an investment economic benefit calculation model; it takes the measured investment demand scale of voltage level into the calculation model of investment economic benefit, and judges the overall performance of the company under the scale of investment demand and the economic benefit of sub voltage level. According to the company's economic performance management and control objectives, whether the company's performance under the investment scheme meets the control requirements is judged. When the performance indicators meet the control requirements, the investment structure scheme based on the investment demand is the final investment plan; when the performance control objectives are not met, the investment scheme is optimized.

\subsubsection{The impact of investment on business efficiency}

Starting from the key elements of the whole value formation chain of "project investment - increase of assets - electricity generated by putting into operation - sales electricity price - profit target of the company", this paper combs the linkage relationship among key indicators - investment, assets, electricity quantity, electricity price, profit and so on.

The impact of investment on profits. The new effective investment will form a support for the future electricity price and electricity, which is conducive to the increase of the company's future profit level; however, the cash gap generated will expand the company's interest bearing debt scale, leading to the increase of debt cost. Meanwhile, the new fixed assets will lead to the increase of depreciation and operation and maintenance expenses. Investment plays a supporting role in the next regulatory period, but has a negative impact on the current profit.

The influence of investment on debt ratio. The new investment will generate additional financing demand, which will expand the company's debt scale and asset scale, but the debt growth rate is higher than the asset growth rate, which will promote the increase of asset liability ratio.

Impact of investment on electricity price. Under the "permitted cost + income" pricing model, the size of investment directly affects the effective asset scale, thus affecting the permitted cost and permitted income level, which is an important factor supporting the transmission and distribution price.

Impact of investment on electricity. The main purpose of investment is to strengthen the grid structure, improve the security and reliability of power supply, and meet the power supply demand of new load, so the investment is conducive to increase the sales of electricity. This study takes historical electricity sales and investment scale as parameters, collects historical electricity sales and investment data, and uses regression method to analyze the quantitative relationship between new electricity sales and electricity sales in the previous period and investment scale of the current period, so as to realize the prediction of electricity sales level under specific investment scale.

\subsubsection{Investment performance index system}

The overall performance of the branch company and the voltage level performance are constructed to realize the economic comprehensive evaluation of the investment economic effect.

The overall performance of the company takes into account the company's performance evaluation index system and price evaluation requirements, and selects three indicators: total profit, asset liability ratio and price evaluation investment scale. Among them, the total profit takes the budget target or performance appraisal standard as the minimum value of total profit; the asset liability ratio is set according to the asset liability ratio control standard of State Grid Corporation. The notice of State Grid Corporation of the people's Republic of China on printing and distributing the work plan of reducing leverage and reducing liabilities (2018) requires that when the company's asset liability ratio is greater than $75 \%$, the annual voltage drop will be $1 \%$; when the asset liability ratio is between $70 \%-75 \%$, the annual voltage drop will be $0.5 \%$; when the asset liability ratio is between $65 \%$ $70 \%$, the annual voltage drop will be $0.3 \%-0.4 \%$; when 
the asset liability ratio is less than $65 \%$, it will not increase every year.

Taking the indicators that can be quantified based on investment as the original value, this paper combs the voltage level performance index system from three aspects of international benchmarking business strength, financial performance and technical economy. The operating strength includes gross profit and net fixed assets; financial performance includes gross profit margin; technical economy includes unit investment transmission electricity and net value ratio. Based on the investment scale, electricity price, line loss rate and other key basic data, this paper calculates the income and cost of sub voltage level, and then calculates the gross profit of sub voltage level.

\subsubsection{Construction of investment benefit calculation model}

By setting profit parameters such as electricity, electricity price and line loss, debt parameters such as financing structure and interest rate, asset parameters such as investment scale, capital transfer rate and depreciation rate, and cash flow parameters such as monetary capital stock, etc., the automatic calculation of fund gap and the automatic output of financial statements and main financial indicators are realized by using the circulation iteration function of Excel.

\subsection{Construction of investment plan}

When the company's economic benefits do not meet the company's performance control requirements under the investment demand, the investment structure scheme is constructed according to the "demand structure, structure balance, heavy and low voltage distribution network, heavy high voltage grid structure, historical structure" and other schemes, and the total investment model meeting the performance objectives under each structure is calculated.

\subsubsection{Optimization of investment scheme based on investment demand structure}

When the company's overall performance index does not meet the company's management and control objectives based on the investment demand scale of different voltage levels, the investment scale of each voltage level is reduced in the same proportion, and the calculated investment structure proportion is brought into the investment benefit calculation model. Based on the planning solution method, the maximum total investment scale meeting the performance objectives is calculated, and the investment scale and investment scale of the company under the investment demand ratio are calculated The investment scale of each voltage level is used as a reference for the investment scheme.

\subsubsection{Construction of other sub voltage level investment scheme}

The investment structure based on power grid demand may be the most suitable for business needs, but it is not necessarily the optimal scheme after considering the power grid benefits and economic benefits comprehensively. Therefore, this study constructs a variety of investment structure schemes from the perspective of "structural balance, heavy and low voltage distribution network, heavy and high voltage grid structure, and historical structure". The investment proportion of each scheme is brought into the investment benefit calculation model, and the maximum investment scale meeting the performance objective constraint under each structure is inversely calculated based on the planning solution technology. The investment scale of each voltage level of each structural scheme is calculated as an alternative investment scheme.

\subsection{Optimization of investment structure with different voltage levels}

The investment scale and structure scheme are brought into the voltage level investment demand calculation model and investment benefit calculation model to calculate the company's economic benefit level and power grid effect under the investment scheme. Establish the investment optimization index system, set the weight of each benefit index, and calculate the comprehensive score under each scheme. The scheme with the highest comprehensive score is taken as the final sub voltage level investment scheme.

\subsubsection{Comprehensive evaluation index system of investment benefit}

Based on the current situation evaluation index and investment benefit index of power grid, the evaluation index system of investment optimization is constructed. Based on the positive and negative change relationship between indicators and strategic objectives, the membership function of the indicators is judged, and the upper and lower limits of the reasonable range of indicators are used as the standard to carry out the quantitative evaluation of indicators. According to the importance of the index, the differential score weight is set, and the total score of the investment evaluation index system is weighted, and the score is used as the basis for the optimization of investment scheme.

The index evaluation system includes the following aspects: investment structure, overall benefit, voltage level performance, main network index and distribution network index. Among them, the main network index and distribution network index reflect the gap between the current equipment status and the target value, and the overall benefit index reflects the gap between the company's operating efficiency and the assessment index. 


\subsubsection{Set scoring criteria}

The membership function type of each index is determined as the basis of score setting. For example, if the capacity load ratio belongs to moderate index, the closer the index is to the reasonable range, the higher the score; the equivalent average load rate is a positive index, the larger the index, the higher the score; the proportion of low voltage users belongs to the reverse index, the smaller the index, the higher the score.

Determine the index scoring standard. The fifth percentile method was used as the evaluation basis. The results of all kinds of indicators were divided into five segments: A, B, C, D and E, in which the highest score was 100 points in a segment and the lowest score was 20 points in E segment.

Determine index weight. The coefficient of variation method was used to calculate the index weight. The variation coefficient method weights each index according to the variation degree of the observed values of all the evaluated objects. Its basic principle is that the greater the variation degree, the greater the impact on the evaluation. The weight reflects the size of the index resolution.

\subsubsection{Optimization of investment scheme with different voltage levels}

Based on the comprehensive evaluation index system and scoring standard of investment benefits, the investment schemes with different voltage levels are set up, and the scores of each index are calculated. At the same time, the comprehensive score of each investment scheme is calculated according to the weight of each index, and the optimal investment scheme is selected based on the highest comprehensive score.

\section{Conclusions}

Through the research on the investment structure of sub voltage level supporting high-quality development, combing the laws of investment and capital transfer, studying the characteristics of optimal power grid structure, quantifying the relationship between investment and grid status indicators and company performance indicators, and building the sub voltage level investment demand calculation model and investment benefit calculation model, which strongly supports the objective and scientific investment decision-making. It optimizes the efficiency and efficiency of the company's resource allocation and promotes the high-quality development of the company and the power grid.

\section{References}

1. Zhu YJ.(2016) Research on optimization method of power grid investment allocation based on Regional Development.Electricity and energy, 37:704-708.

2. Zhang Y,(2018)Discussion on investment plan management of power grid infrastructure project based on quality improvement and efficiency improvement.Enterprise reform and management,43-
44.

3. Yang N,Liu DN,Liu MG,Ye B,Ma J,Li XT.(2020) Differentiated investment strategy of provincial power grid considering the development stage of prefecture and city. Power system automation. Power system automation,44:115-122

4. Li M,Li XD.(2016)Research on investment allocation model of power grid enterprises based on investment capability. Northeast Electric Power Technology, $01: 19-23+33$ 